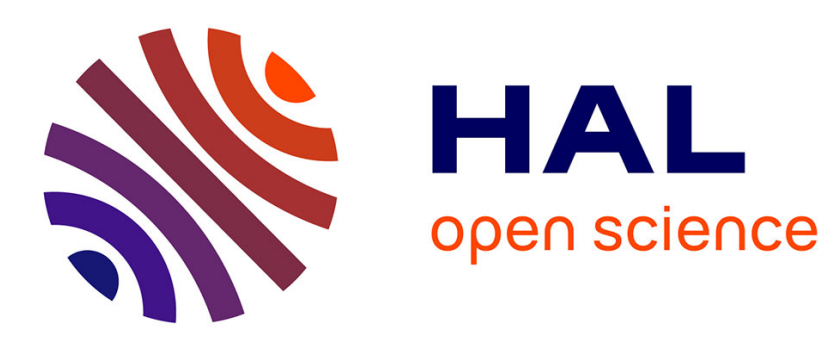

\title{
Social Inequalities in the French Education System : The Joint Effect of Individual and Contextual Factors
}

\author{
Marie Duru-Bellat
}

\section{To cite this version:}

Marie Duru-Bellat. Social Inequalities in the French Education System : The Joint Effect of Individual and Contextual Factors. Journal of Education Policy, 2000, 15 (1), pp.33-40. hal-03209790

\section{HAL Id: hal-03209790 \\ https://hal.science/hal-03209790}

Submitted on 7 Jun 2021

HAL is a multi-disciplinary open access archive for the deposit and dissemination of scientific research documents, whether they are published or not. The documents may come from teaching and research institutions in France or abroad, or from public or private research centers.
L'archive ouverte pluridisciplinaire HAL, est destinée au dépôt et à la diffusion de documents scientifiques de niveau recherche, publiés ou non, émanant des établissements d'enseignement et de recherche français ou étrangers, des laboratoires publics ou privés. 


\title{
Social inequalities in the French education system: the joint effect of individual and contextual factors
}

\author{
Marie Duru-Bellat \\ Article publié dans Journal of Educational Policy, 2000, vol.15, $n^{\circ} 1, p .33-40$ \\ https://www.tandfonline.com/doi/abs/10.1080/026809300285999
}

Marie Duru-Bellat is a Professor of Education at the University of Burgundy. She has conducted several research studies at the Institut de Recherches en Economie de l'Education (IREDU-CNRS), on topics such as gender inequalities, educational democratization in European countries, school effectiveness and school choice. She has recently published (with A. Mingat) Pour une approche analytique du fonctionnement du système éducatif (Paris: PUF, 1993) and (with A. Van Zanten) Sociologie de l'école (Paris: A. Colin, 1999).

Abstract :

This paper presents a synthetic picture of social inequalities in pupils' scholastic careers in France. Individual factors such as socio-economic background remain important for bath academic results from the beginning of schooling on and option and streaming choices at the secondary level. Moreover, families have unequal resources to manage their children's schooling careers in a system which is becoming more complex and decentralized. This means that contextual factors are also very important. Decentralization has in fact increased the importance of choice of schooling context: the class or the school attended does make a difference and this has the effect of widening social gaps in academic results and socialization. The present trend towards more autonomous schools fosters inequalities resulting from contextual factors but inequalities are also produced by the downgrading of degrees resulting from the fact that employers are requiring ever-higher degrees in a period of job shortage.

In France like in most industrialized countries, there has been an opening up of educational opportunities, during the last thirty years: thus, the proportion of a generation reaching the level of the baccalauréat the upper secondary school leaving diploma - rose from $20 \%$ in 1966 to $40 \%$ in 1986, and was up to $68 \%$ in $19 \%$. However, at the same time, schooling careers continue to be marked by strong social inequalities: among 20-21-year-olds (in 1996), 51\% of the children of manual workers reach the level of the baccalauréat, compared with $87 \%$ of the children of top executives, teachers or lower service class members (DEP 1997). Until recently, these differences have been mostly analysed as being related to families' cultural resources, the pupils being, according to their background, more or less in phase with the contents and the values of an institution unconcerned about the differences between pupils ('indifférente aux différences', Bourdieu said).

From the 1980s onwards, in connection with the growing prevalence of a less deterministic conception of social phenomena, and a more assertive one concerning the actor, more attention has been given to the context in which these social inequalities are generated, through various social processes. The context, which is first of all the school attended, but also the teachers themselves and their pedagogical practices, or the way pupils are grouped in classes, and more broadly, the organization of the system itself, which lays the framework in which actors behave. After having briefly set out the present state of social inequalities at the different levels of the system, ${ }^{1}$ we shall analyse how contextual factors can appear finally on their own to be an important factor in the inequalities between pupils.

\section{Inequalities in academic achievement, and in educational choices, at the successive levels of schooling}

Early and cumulative inequalities in academic progression 
In France, almost every child benefits from preschool education from age three (99.6\% in 95-96), even if the compulsory age for schooling is six. However, preschool education remains slightly delayed among children of farmers or unskilled manual workers. That is not unimportant, because the longer the preschool education, the better one succeeds within primary school, especially at the first level (Cours Préparatoire - CP). The level of achievement at that level (CP) proves to be strongly linked with social background: among pupils having entered into the lower secondary school - collège - in 1989 , about $20 \%$ of the children of manual workers have repeated the CP, compared with $2 \%$ of teachers' children. Repeating a year is still quite common in France, even if research shows that it does not help pupils sufficiently in overcoming their academic weaknesses, and that repeating has even some detrimental impact upon future progress. At the end of primary education, social inequalities in knowledge (measured by standardized tests) are already quite large: when entering collège, differences of 17 points has been observed, in French, between children of manual workers and pupils of top executives (the mean score being about 66 points); the difference amounts to 18 points in mathematics (the mean score being about 63 points). ${ }^{2}$

\section{Unequal 'choices' in the search for difference}

The social inequalities already generated when leaving the primary school widen within the lower secondary school - the collège ${ }^{3}$ - through two distinct mechanisms.

The first one concems progression: within collège, academic attainment differs according to social background; social inequalities over time are even stronger than during primary education (Duru-Bellat and Mingat 1993). Morever, secondary education in itself widens the inequalities in achievement observed at the beginning: pupils who are good achievers when entering collège progress more than pupils who are weak from the outset.

Furthermore, two specific processes generating inequalities are at work at the collège level: subject option choices, and (still more important) streaming mechanisms. Even if the structure of the collège has been progressively unified, there is a first choice to be made right from the first level (6ème), concerning the study of a foreign language; this choice proves to be related to social background, since, for instance, $26 \%$ of teachers' children choose to study German, compared with $8 \%$ of children of manual workers.

What is true for option choices is even more valid as far as streaming choices are concerned, especially at the end of collège; alternative routes are: entering into the upper secondary school (the lycée), to prepare for three years for the baccalauréat, be it a general or a technological one, or beginning vocational training lasting two years (brevet d'études professionnelles). As expected, these choices are related to the academic level of pupils, and the best pupils will follow, on average, the longest and the most prestigious tracks, while, on the contrary, vocational ones are perceived as relevant only for academically poor pupils. But streaming decisions differ markedly according to pupils' social background. Among pupils who have not repeated during the collège years (having not experienced important problems), $77 \%$ of top executives or teachers' children enter into the lycée, compared with $32 \%$ among manual workers' children.

Those differences are mainly the outcome of families' demands. While parents are conscious that they should give up the most demanding tracks when their child is academically too weak, this selfselection operates more or less importantly, according to the social background, especially when the child's achievement is average or slightly weak: families of low socioconomic status, who are more afraid of the risk of a failure in subsequent studies, prove to be more cautious and abandon asking for general tracks, i.e. the most prestigious ones, and fall back on a vocational route. Actually, teachers in charge of the decision-making process strive to follow families' demands; they do not modify the 'choices' of those who express strongly selective demands, thus ratifying and exacerbating the social inequalities produced by those 'choices'.

The way pupils and families choose and more broadly manage their schooling career becomes still more important in the upper secondary school. At this level, the different tracks become more specialized, and pupils' social background often proves relevant in this respect: the proportion of top executives' children (which is about 16\% among the 20-24-year-olds) decreases from the tracks leading to the general baccalauréat (33\%) to the technological (14\%) and the vocational ones (11\%). Within the general tracks, the different types are not chosen randomly: more children from high SES choose the scientific 
baccalauréat $\mathrm{S}$ than the social sciences (ES) and the humanities ones (L). This is pre-empted by options choices, made within the lycée, which are connected with each other, but not according to what would be 'pedagogically' logical: it is among pupils who have chosen to study Latin in the first year of the lycée (2nde) that the percentage of choices for a scientific second year is the highest; those pupils, having managed to enter into what is the most prestigious route, will often drop this subject which has become irrelevant. We observe too that pupils having studied Latin in the first year and having not succeeded in entering into a scientific second year (lère), 'prefer' entering an economic one rather than a literary one, which again reveals a positional logic (since the economic baccalauréat is the 'second best' choice), rather than a pedagogical one.

Considering that in France, there is a strong link between the type of baccalauréat you obtain and which tertiary study you can follow, the choices within higher education will be marked by social inequalities: the proportion of top executive and teachers' children is $32.5 \%$ in the first level of academic university tracks, with open access, $13.5 \%$ in the two year tracks leading to a precise job at a lower executive level, and amounts to $48.5 \%$ in the special classes leading (after hard competition) to élite schools (grandes écoles). The over-representation of pupils from high SES grows with the prestige of different schools, in such proportions that those pupils make up more than $80 \%$ of the student body of schools such as Polytechnique, or the École Nationale d'Administration (Euriat and Thélot 1995).

On the whole, in tertiary education, where managing his or her own career requires from the student very sophisticated knowledge or know-how, orientation in a broad sense (including choosing another course in case of failure, choosing the best place to study, etc.) becomes the main process through which social inequalities are generated. Actually, at this level, no more social inequalities related to academic achievement are observed, which would be in addition to the schooling value one has accumulated during primary and secondary schooling.

From primary to tertiary education, a continuous process thus goes on: being behind agewise and having difficulties from the beginning of primary school, pupils from low SES enter into the secondary level and face the latter's streaming processes with an handicap as far as global levels of achievement are concerned. At the secondary level, significant social inequalities of attainment occur, at least till the first year of the upper secondary school. Nevertheless in addition, social inequalities concerning 'demand' appear each time a choice is to be made (for pupils of similar level of achievement). On the whole, social inequalities do not become blurred through time, but accumulate; and the more one goes along in the educational system, the more social inequalities of academic achievement diminish, compared with social inequalities linked to choices and orientation. In the $1980 \mathrm{~s}$, the social difference in the rate of access to the first form of the lycée (between children of manual workers and of top executives) was explained by three roughly equal components: inequalities in achievement within primary schooling, inequalities in achievement within collège, and orientation processes within the secondary level (DuruBellat 1996).

In a context of strong widening of educational opportunities, within a more and more diverse and complex system, social inequalities linked to orientation will certainly have a growing importance. This is not without ambivalent consequences upon youngsters' representations of the function of school in their own social trajectory, especially for those who, thirty years before, would have had no chance at all to enter into secondary education. Children from low SES face a progressive exclusion (or relegation towards the least prestigious tracks), which probably makes them more stigmatized than in the past: ${ }^{4}$ they appear to have been offered some opportunity, and their schooling career appears to result solely on merit; what those youngsters 'excluded from within' feel in schools (their expérience scolaire) is often very harsh (Dubet and Martucelli 1996).

\section{The schooling context does make some difference}

Until the changes of the 1980s (cf. Broccolichi and van Zanten, and Derouet, 2000), the centralization prevailing in France has diverted attention away from looking at contextual effects in the generation of schooling careers. However, the latter did take place in diversified contexts, which may be not neutral as far as inequalities between pupils are concerned. In particular, collèges may differ to a large extent in the social characteristics of their pupils (for instance, the proportion of manual workers' children may vary from $10-80 \%$ according to schools). 


\section{School effects as far as progression and orientation are concerned}

If French primary schools do not differ significantly in their ability to help their pupils progress, nevertheless, significant schools effects are observed both at collège and at lycée levels (Bressoux 1994). Schools where pupil progress is strongest implement an efficient management of time and discipline; they also have positive expectations regarding the attainment of their pupils, and achieve a good coverage of the curriculum's contents; these school characteristics, which prove to be linked with a better efficiency are more often found together in schools attended by pupils from high SES (Grisay 1997).

Besides, schools attended by a majority of pupils from high SES tend to be less selective as far as tracking is concerned than those which cater for a majority of low SES pupils. It seems as if each school, consciously or not, adapts its orientation practices to its majority of 'customers'; the school tends thus to be less selective when the pupils are from middle or high social classes or more selective when the opposite appears. Thus there are contextual effects attached to every pupil in the school: for instance, pupils from low SES attending 'posh' schools get access to more prestigious tracks than when attending working class schools, which is by definition more often the case (Cousin 1996). In fact, this results from pupils' choices: the pupils are led to adopt the attitudes and values of the group that is numerically dominant in the school: in the 'posh' collèges, the prevailing high level of educational aspirations pulls toward the top the demand of every pupil, especially those from low SES, the demands of the latter consequently prove more ambitious. Since decisions about tracking set out to follow youngsters' demands, it becomes understandable that 'posh' schools prove to be less selective (Duru-Bellat and Mingat 1993).

\section{The influence of teachers, their practices, and the way pupils are grouped in classrooms}

Some differences emerge as much or even more often at the class level. This is particularly true as far as progress is concerned: these prove more variable from one class to another than between schools, especially at the primary level. During the first year (CP), for instance, progress is more influenced by the pupil's teacher than his or her social background (Mingat 1991). Academically weak pupils are more prone to these teacher effects; the result is that efficient teachers distinguish themselves by their ability to make this kind of pupil progress more, the inequalities in achievement between pupils being consequently less important in their classes.

The concrete teaching practices of those teachers have seldom been studied in France. But it seems that no practice proves to be efficient in every given context. If research is unanimous in stressing the impact of the pupil's active learning time and of teachers' positive expectations, most of the relationships between practices and progress vary according to the kind of pupils studied (Bressoux 1994). For instance, with pupils from high SES, the most efficient teachers are very demanding, foster a high level of stimulation, and often criticize; while with pupils from low SES, it is more efficient to encourage, to try and motivate and to play clown criticisms, etc. However, some results seem more straightforward: thus a lot of practices aimed at making some differentiation in teaching do in fact widen the inequalities between pupils. This is particularly so as far as the setting up of ability groupings is concerned.

In France, a random grouping of pupils in each class is supposed to be implemented at each level. However, at least at the collège level, a large share of collèges implement some ability grouping (only about $20 \%$ do not put together pupils within classes this way). They do so, ail the more because they are attended by low SES pupils. In a context of growing competition between schools, collèges would try to keep some academically good pupils, by offering them some 'protected' classes (Payet 1995). Actually, at the collège level, ability grouping widens markedly differences between pupils, with better progress in high level classes and poorer ones in weak level classes, especially when these are also homogeneous (Duru-Bellat and Mingat 1997). As we have already mentioned, some ability grouping is achieved through the choice of a foreign language or rare subject; these choices also prove to be marked by social background; the result is that the best pupils, and pupils from the most privileged background are put together in the same classes and in the same schools (cf. Broccolichi and van Zanten, 2000). Besides, the influence of the kind of class attended overlaps on to academic performances; it concerns 
too every day socialization, especially attitudes toward school and the image one has of oneself. At the collège level, pupils' confidence (and their parents') in their subsequent schooling career varies more according to the class they belong to than to the school attended (Grisay 1997).

On the whole, a substantial part of the high SES pupils' advantage in schooling rises from the fact that they have access to schools that give them better working conditions (more efficient schools, less selective as far as tracking is concerned, often receiving more resources, high level classes, etc.). ${ }^{5}$ Conversely, it seems difficult to put in place a climate favourable to learning and fostering a positive experience of schooling when the school brings together mostly low SES children. More generally, access to a specific schooling context, and the choice of this context by actors is becoming more and more a crucial factor in the generating of social inequalities in schools.

\section{Often underestimated, the influence of the supply of schools and of institutional and organizational factors}

Finally, context also includes the way schooling careers and orientations are formally (institutionally) regulated. For instance, the way formal directives organize tracking is very important: to suggest to teachers (as it is the case in France) to follow families' demands leads to the social bias those demands incorporate into the decision. This is all the more true when official rules do not implement any selection (as is most often the case at the tertiary level), as self-selection will prevail, in tune with social bias, as already mentioned.

Besides, after the baccalauréat, youngsters' choices take place in a context characterized by a specific geographic distribution of schooling opportunities. In average towns where more and more often tertiary institutions are present, youngsters' choices (especially when they are from low SES background) tend to concentrate on the tracks offered locally. In this respect, economic factors do intervene, as being a student is much less expensive when you can stay in your own town. Even if creating possibilities of tertiary education in average towns aims at democratizing access to this level, the fact is that it is students from low SES who prove to be the most influenced by the local opportunities; the fact that their choices are consequently distorted by supply locally leads to a real risk - from a social point of view - of a dual university.

In summary, the overall pattern of the relationships between education and jobs affects individual strategies. In France, some diplomas are now being downgraded (as far as wages or social status are concerned); nevertheless, the comparative level of education continues to remain valuable when one is looking for a job, in a context of job shortage, resulting in a chain of depreciation of diplomas, except for the highest ones. Youngsters act quite soundly in trying to accumulate diplomas, as, if the return of one degree may prove to be devalued, it remains however, necessary, if you want to get in the front of the queue for jobs. These trends are all the more pronounced in France as general training is the dominant way to rank people and allocate them jobs within firms, a 'level of education' logic prevailing upon a logic of vocational training. The fact remains that, like monetary inflation, this relative downgrading of diplomas may widen social inequalities.

\section{Conclusions}

This short presentation of social inequalities in the French educational system shows that democratization in school is far from achieved; the fact is that, underlying macro-sociological regularities, actors, with unequal assets, strive to use the system in the way they consider to be in their own interest. Even if educational structures have on the whole evolved towards unification, actors use these structures to continuously re-implement new differentiations, aimed at positioning their children along a unique hierarchical line running, at the baccalauréat level for instance, from the scientific option clown to the technological ones. In this respect, the best route to take is the one which gives access to tertiary tracks considered to be the most promising as far as employment prospects are concerned, even if the former's academic content is not perceived as very attractive. This logic produces a lot of instrumental 'second best' choices; in this context, the notion of personal and genuine plans, so valued in official texts, does not prove very relevant and even appears as a double bind: this is because if a pupil is academically good, he or she will be persuaded, whatever his or her preferences may be, to try and enter into a scientific route, and will be firmly advised to do so, because it seems to 
be the 'normal' choice for good pupils.

Besides, choosing the right subject, and, more and more often, the right school, requires up to date information about how the system operates informally. In no official booklet will you find that an effective way to get a scientific baccalauréat is to choose Latin in the first year of the lycée. As Bourdieu and Passeron have said (1970), for cultural goods in general, the choice of a subject presupposes 'possession of the cultural code required for decoding the objects displayed'.

In other respects, we wish to stress that the development towards more autonomous schools, which is encouraged today in France, may, if no political regulation is implemented, lead to new social differences. The difference between listening to school users and being de facto submitted to their pressures is frequently blurred at the local level. The developments observed today in France lead to the same conclusion as the ones made by Ball in 1993, according to which 'choice and the market provide a way for the middle-classes to reassert their reproduction advantages in education, which had been threatened by the increasing social democratic de-differentiation of the schools'.

\section{Notes}

1. We will focus here on inequalities linked co the pupil's social background, without dealing with the specific influences of his or her ethnie background (which is in fact very small), or with the impact of gender (positive for girls in many respects).

2. We will use here the father's profession to characterize the child's social background but let's recall that the educational level of parents, especially the mother's is also associated wich academic achievement (Caillé and Vallet 1996)

3. It is only since the 1975 Educational Act (implemented in 1977) chat the French college became truly comprehensive (on paper), the separate streams being abolished and ail the pupils being supposed to receive the same education up to the age of 15 or 16 .

4. Before the sixties only children from high SES entered into secondary school; it was perceived as an inequality for which society was deemed responsible, but not school in itself; skill-linked inequalities between people were not considered as relevant in trying to explain the above inequalities.

5. In tertiary education, per student expenditure is much higher in élite schools (the average unit cost is about $\$ 13000$ in the grandes écoles compared with $\$ 5000$ in universities.

\section{References}

BALL, S. J. (1993) Education markets, choice and social class: the market as a class strategy in the UK and the USA, British Joumal of Sociology of Education, 14 (1), 3-19.

BOURDIEU, P. and PASSERON, J-C. (1970) La Reproduction (Paris:Editions de minuit).

BRESSOUX, P. (1994) Les recherches sur les effets-école et les effets-maitres, Revue Française de Pédagogie, 108, 91 137.

BROCCOLICHI, S. and VAN ZANTEN, A. (2000) School competition and pupil flight in the urban periphery, Journal of Education Policy, 15, 51-60.

CAILLE, J. P. and VALLET, L. A. (1996) Les élèves étrangers ou issus de l'immigration dans l'école française, in Les Dossiers d'Education et Formations, (Paris: DEP-MEN), 67.

COUSIN, O. (1996) Construction et évaluation de l'effet établissement: le travail des collèges, Revue Française de Pédagogie, 115, 59-75.

L'Etat de l'Ecole (1997) (Paris: DEP, Direction de PEvaluation et de la Prospective/Ministère de l'Education), 7.

DEROUET, J-L. (2000) School autonomy in a society with multi-faceted political references: the search for new ways of coordinating action, Journal of Education Policy, 15, 61-69.

DUBET, F. and MARTUCELLI, D. (1996) A l'école. Sociologie del'expérience scolaire (Paris: Seuil).

DURU-BELLAT, M. (1996) Social inequalities in French secondary schools: from figures to theories, British journal of Sociology of Education, 17 (3), 341-350.

DURU-BELLAT, M. and MERLE, P. (1997) La démocratisation impossible ? Usages sociaux de l'école et inégalités sociales des cursus scolaires, Savoir, 3/4, 3-24.

DURU-BELlAT, M. and MINGAT, A. (1993) Pour une approche analytique du fonctionnement du système éducatif (Paris: PUF).

DURU-BELLAT, M. and MINGAT, A. (1997) La constitution de classes de niveau par les collèges: les effets pervers d'une pratique à visée égalisatrice, Revue Française de Sociologie, XXXVIII, 759-790.

DURU-BELLAT, M. and VAN ZANTEN, A. (1999) Sociologie de l'Ecole (Paris: A. Colin). 
EURIAT, M. and THELOT, C. (1995) Le recrutement social de l'élite scolaire depuis 40 ans, Éducation et Formations, 41, 3-21.

GRISAY, A. (1997) L'évolution des acquis cognitifs et socio-affectifs des élèves au cours de années de collège, in Les Dossiers d'Education et Formations (Paris : DEP-MEN), 88.

MINGAT, A. (1991) Expliquer la variété des acquisitions au cours préparatoire: les rôles de l'enfant, la famille et l'Ecole, Revue Française de Pédagogie, 95, 47-63.

PAYET, J. P. (1995) Collèges de banlieue (Paris: Méridiens-Klincksieck). 